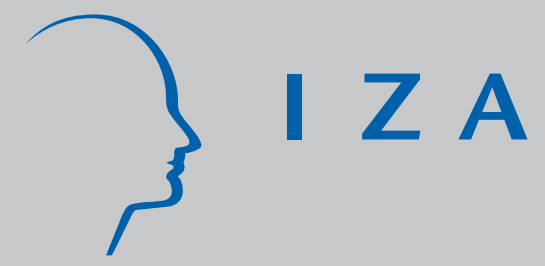

IZA DP No. 8112

Gender Pay Gaps among Highly Educated Professionals:

Compensation Components Do Matter

Christian Grund

April 2014

Forschungsinstitut zur Zukunft der Arbeit Institute for the Study of Labor 


\title{
Gender Pay Gaps among Highly Educated Professionals: Compensation Components Do Matter
}

\author{
Christian Grund \\ RWTH Aachen University \\ and IZA
}

Discussion Paper No. 8112

April 2014

IZA

P.O. Box 7240

53072 Bonn

Germany

Phone: +49-228-3894-0

Fax: +49-228-3894-180

E-mail: iza@iza.org

\begin{abstract}
Any opinions expressed here are those of the author(s) and not those of IZA. Research published in this series may include views on policy, but the institute itself takes no institutional policy positions. The IZA research network is committed to the IZA Guiding Principles of Research Integrity.

The Institute for the Study of Labor (IZA) in Bonn is a local and virtual international research center and a place of communication between science, politics and business. IZA is an independent nonprofit organization supported by Deutsche Post Foundation. The center is associated with the University of Bonn and offers a stimulating research environment through its international network, workshops and conferences, data service, project support, research visits and doctoral program. IZA engages in (i) original and internationally competitive research in all fields of labor economics, (ii) development of policy concepts, and (iii) dissemination of research results and concepts to the interested public.
\end{abstract}

IZA Discussion Papers often represent preliminary work and are circulated to encourage discussion. Citation of such a paper should account for its provisional character. A revised version may be available directly from the author. 
IZA Discussion Paper No. 8112

April 2014

\section{ABSTRACT}

\section{Gender Pay Gaps among Highly Educated Professionals: Compensation Components Do Matter}

Making use of panel data from a survey of highly educated professionals, gender pay gaps are explored with regard to total compensation as well as to individual compensation components. The results indicate meaningful male-female wage differentials for this quite homogeneous group of people working in one specific industry: in particular for more experienced employees in higher positions of firm hierarchies with children. Gender pay gaps are much more pronounced for bonus payments than they are for fixed salaries.

JEL Classification: M52, J31, J33

Keywords: bonus payments, fixed salaries, gender wage gap, management compensation

Corresponding author:

Christian Grund

RWTH Aachen University

School of Business and Economics

Templergraben 64

D-52056 Aachen

Germany

E-mail: christian.grund@rwth-aachen.de 


\section{Gender Pay Gaps among Highly Educated Professionals - \\ Compensation Components Do Matter}

\section{Introduction}

The principle of equal pay for male and female workers for equal work is supposed to be applied in many countries, such as the USA (Equal Pay Act of 1963) or those of the EU (Article 157 of the Treaty on the Functioning of the European Union). Yet, in spite of a slow convergence (Blau \& Kahn 2006), gender wage gaps are still prevalent and are comprehensively discussed in research and practice (e.g. Arulampalam et al. 2007, Christofides et al. 2013 for international comparisons). Raw gender wage gaps can partly be explained by some differences in individual and in job characteristics. To some extent women and men select different jobs so that job segregation occurs, which is a crucial issue when measuring wage gaps (e.g. Bayard et al 2003, Olivetti \& Petrongolo 2008). Therefore, the results for gender wage gaps in empirical studies have to be interpreted with regard to the heterogeneity of jobs and individuals in the samples and with regard to the possibilities to control for this heterogeneity. Many studies build on representative surveys with quite heterogeneous individuals and jobs in many different industries. It is then questionable as to whether they succeed in capturing the main differences.

In contrast, this contribution builds on a rather homogenous group of highly educated and well qualified professionals, who work as managers in the German chemical sector. A major part of heterogeneity among employees is thus ruled out, and labor supply decisions are taken as given.

Previous studies usually examine gender gaps in gross monthly wages or yearly income. Gaps, however, may differ across components of compensation. For instance, taxonomies of determining (changes in) fixed salaries can differ from those for defining bonus payments. The main objective of this study, therefore, is to examine possible differences in gender pay gaps for compensation components, thereby distinguishing between fixed salaries, bonus payments, and other payments.

The results of this contribution do reveal evidence for component-specific gender wage gaps. Gaps for bonus payments considerably overtop those for fixed salaries. Gender pay gaps 
increase with experience and the level of the hierarchy, and are higher for employees with children.

I describe the data and variables in the following section 2, and present raw pay gaps there. Subsequently, I present the empirical results (section 3), before I conclude (section 4).

\section{Data, variables, and raw gender pay gaps}

I use data from a yearly salary survey among professionals and managers from the German chemical sector for the years 2008 to 2012. The survey was conducted together with the German Association of Employed Academics and Executives in the Chemical Industry (Verband angestellter Akademiker und leitender Angestellter der Chemischen Industrie e.V. (VAA)). The survey is sent out to all members of the association and we get a return rate of 0.3 each year. According to the Association, our sample is representative of the appropriate employees in the German chemical industry. The German chemical sector significantly contributes to the economy, e.g. with 15 percent of German exports. The sector is dominated by large firms, e.g. BASF and Bayer, which belonged to the world top 100 firms word wide in terms of shareholder value in 2012. In order to get a rather homogeneous sample of employees, I restrict the sample to persons holding a doctoral degree in natural sciences or engineering. In particular for the discipline chemistry, it is very common in Germany for students to take a doctoral degree following their Master. Employees in part-time positions are not taken into account. This applies to 0.16 of the females, but to less than 0.01 of the males. Furthermore, I excluded top managers from the analysis, since their compensation contracts differ considerably from those of middle managers.

These restrictions lead to an unbalanced panel of 16,029 observations with 7,021 different persons in the five-year observation period. The sample is dominated by males. There are 1,737 observations (0.11) of females, though. The data contain detailed information on compensation. Next to total yearly compensation, I also explore pay components individually. Fixed salaries account for 80 percent of compensation. The vast majority of employees receive a bonus payment, which accounts for 16 percent of total compensation on average. Other payments include stocks and stock options, specific compensation for inventions, and supplementary payments, such as anniversary bonuses, for instance. Table 1 shows averages in total compensation and its components by sex. Compensation for women is considerably 
lower. The average total compensation of males exceeds the compensation of females of 22 percent. Remarkably, the gap within this very homogenous group of employees is almost exactly the gap reported by the OECD employment outlook report in 2008 among all fulltime working employees in Germany. The raw gender pay gaps differ across components. The gap is less pronounced for fixed salaries (0.15) compared to bonuses $(0.46)$ or other payments (1.31). The larger differences for contingent payments are partly driven by larger shares of women who do not receive any bonus or any other payment. Whereas over 0.90 (0.60) of males receive positive bonus (other) payments, this is true only for 0.85 (0.45) of females. These raw gender pay gaps are not only prevalent at the mean but over the whole distribution of compensation (see Figure 1 in the appendix).

Table 1: Mean amount of pay components by sex and raw gender pay gaps

\begin{tabular}{llll}
\hline & $\begin{array}{l}\text { Females } \\
(\mathrm{n}=1,737)\end{array}$ & $\begin{array}{l}\text { Males } \\
(\mathrm{n}=14,292)\end{array}$ & Gap \\
\hline Total compensation & $99,462 €$ & $121,210 €$ & 0.22 \\
& & & \\
Fixed salary & $83,529 €$ & $95,823 €$ & 0.15 \\
& $13,400 €$ & $19,535 €$ & 0.46 \\
Bonus payment (all) & 0.855 & 0.910 & 0.37 \\
$\quad$ Share of bonus $>0$ & $15,674 €$ & $21,473 €$ & 1.31 \\
Bonus payment (if received) & $2,533 €$ & $5,852 €$ & 0.64 \\
Other payments & 0.451 & 0.634 \\
$\quad$ Share of other $>0$ & $5,620 €$ & $9,232 €$ & \\
$\quad$ Other payments (if received) & & & \\
\hline
\end{tabular}

Although, I use a rather homogeneous sample of employees, these differences in compensation might be explained by gender differences in some individual and job based characteristics (see Table 2). The subject of the academic degree held has explained some amount of the gender wage gap in previous studies (Machin \& Puhani 2003). I can distinguish eight different fields of study. The vast majority studied chemistry. More males have a degree in engineering, whereas a larger share of females studied pharmacy, biology, or medicine. Experience - another factor in explaining gender pay gaps (e.g. Munasinghe et al. 2008) - is measured in years from the undergraduate degree (German "Diplom”, Master), so that the duration of working towards the doctoral degree counts as experience. This is because the 
majority of doctoral students works on projects that are similar to those of typical starting positions in firms. Other ways of operationalization or using age instead of experience do not change the results, though. Males are somewhat more experienced than females. I have no direct information on gaps in the employment history. Dismissals are extremely rare in the German chemical sector, so that employees have hardly any unemployment spells. I will use information on employees' children to account for possible parental leave in a separate analysis and as a possible interaction effect with sex (see e.g. Ruhm (1998) or Ejrnaes \& Kunze (2013) for examinations of economic consequences of parental leave mandates). In fact, it is only recently that a larger share of males have started to take parental leave in Germany, as the government introduced a tax-financed payment in 2007 for parents taking parental leave for up to 14 months. Only one quarter of the females have children compared to more than two thirds of the males in this sample.

Job characteristics are also taken into account. Employment relationships are quite stable in the German chemical sector. Average tenure amounts to almost 15 years. I can distinguish between three levels of firms' hierarchies. Individuals are asked to allocate themselves to levels from level 4 (some management responsibilities) to level 2 (senior management). The top management (level 1) is excluded because of essentially different compensation principles, as described above. I can distinguish between nine functional areas. The majority work in R\&D (0.40) and production (0.18). Firm size is measured by the number of employees in eight categories. The German chemical industry is dominated by large firms. More than half of the individuals in the sample work in firms with more than 5,000 employees. Levels of the hierarchy are at least comparable within firm size categories. The observations are rather equally distributed over years. Additionally, I have information on weekly working hours for a majority of observations. In contrast to more heterogeneous samples, there are no gender differences in working hours here and results are not affected at all. I decided to remove working hours from the analysis in order not to lose observations. 
Table 2: Descriptive statistics

\begin{tabular}{|c|c|c|c|c|c|c|}
\hline & \multicolumn{2}{|c|}{ Whole Sample } & \multicolumn{2}{|c|}{ Females } & \multicolumn{2}{|c|}{ Males } \\
\hline & Mean & SD & Mean & SD & Mean & SD \\
\hline \multicolumn{7}{|l|}{ Individual characteristics } \\
\hline Children (1=yes) & 0.635 & & 0.259 & & 0.680 & \\
\hline $\begin{array}{l}\text { Experience (years) } \\
\text { Field of study }\end{array}$ & 20.59 & 7.872 & 17.44 & 7.872 & 20.97 & 7.787 \\
\hline Chemistry & 0.719 & & 0.609 & & 0.733 & \\
\hline Engineering & 0.082 & & 0.035 & & 0.088 & \\
\hline Biology & 0.056 & & 0.116 & & 0.048 & \\
\hline Physics & 0.032 & & 0.010 & & 0.035 & \\
\hline Medical science & 0.020 & & 0.054 & & 0.015 & \\
\hline Pharmaceutics & 0.057 & & 0.115 & & 0.050 & \\
\hline Other natural science & 0.034 & & 0.061 & & 0.031 & \\
\hline \multicolumn{7}{|l|}{ Job characteristics } \\
\hline $\begin{array}{l}\text { Tenure (years) } \\
\text { Level of hierarchy }\end{array}$ & 14.61 & 8.602 & 10.99 & 7.764 & 15.05 & 8.595 \\
\hline Level 2 & 0.150 & & 0.079 & & 0.159 & \\
\hline Level 3 & 0.531 & & 0.461 & & 0.540 & \\
\hline \multirow{2}{*}{\multicolumn{7}{|c|}{ Functional area }} \\
\hline & & & & & & \\
\hline Production & 0.180 & & 0.093 & & 0.191 & \\
\hline Research and development & 0.403 & & 0.487 & & 0.393 & \\
\hline Technology & 0.039 & & 0.014 & & 0.042 & \\
\hline Applications engineering & 0.071 & & 0.066 & & 0.072 & \\
\hline Sales, marketing, logistics, sourcing & 0.086 & & 0.084 & & 0.086 & \\
\hline Finance, controlling, human resources & 0.037 & & 0.027 & & 0.038 & \\
\hline Technical supervision & 0.059 & & 0.050 & & 0.060 & \\
\hline IT & 0.015 & & 0.007 & & 0.016 & \\
\hline Other & 0.109 & & 0.174 & & 0.102 & \\
\hline \multicolumn{7}{|l|}{ Firm size (number of employees) } \\
\hline Less than 100 & 0.045 & & 0.051 & & 0.045 & \\
\hline 101 to 300 & 0.052 & & 0.055 & & 0.052 & \\
\hline 301 to 1,000 & 0.108 & & 0.115 & & 0.107 & \\
\hline 1,001 to 2,000 & 0.098 & & 0.109 & & 0.097 & \\
\hline 2,001 to 5,000 & 0.124 & & 0.110 & & 0.126 & \\
\hline 5,001 to 10,000 & 0.117 & & 0.104 & & 0.118 & \\
\hline 10,001 to 30,000 & 0.256 & & 0.283 & & 0.253 & \\
\hline More than 30,000 & 0.200 & & 0.174 & & 0.203 & \\
\hline \multicolumn{7}{|l|}{$\underline{\text { Year }}$} \\
\hline 2008 & 0.200 & & 0.176 & & 0.204 & \\
\hline 2009 & 0.208 & & 0.191 & & 0.210 & \\
\hline 2010 & 0.203 & & 0.218 & & 0.201 & \\
\hline 2011 & 0.202 & & 0.214 & & 0.196 & \\
\hline 2012 & 0.188 & & 0.202 & & 0.187 & \\
\hline Number of observations & 16,029 & & 1,737 & & 14,292 & \\
\hline
\end{tabular}




\section{Empirical results}

The gender pay gaps are analyzed in more detail by applying Mincer type wage regressions using random effects panel estimations. The log of compensation and its components act as dependent variables. Since not every manager receives a bonus payment (or other payments) and the log of zero is not defined, corresponding estimations are complemented by random effects Tobit estimations with absolute bonus or other payments as dependent variables. I start by estimating three specifications for total compensation: (1) only taking sex and year dummies into account, (2) additionally controlling for individual characteristics and (3) controlling for individual and job characteristics (see Table 3). The conditional gender wage gap - expressed by $e^{x}-1$ of the estimated coefficient for female $x$-does decrease from 0.16 in model (1) to 0.07 (model 2) and to 0.06 (model 3). However, there are still highly significant and economic meaningful gender gaps in total compensation for this homogeneous group of employees controlled for important characteristics of their jobs.

Gender pay gaps need not necessarily be the same for all groups of employees. The female dummy is interacted with children, experience, and hierarchy levels in addition to the characteristics considered in model (3) of Table 3. Results are shown in Table 4. The gender wage gap is larger for employees with children, indicating that parental leave is much more pronounced for mothers than for fathers. However, significant gender differences also hold for employees without children. Gender gaps are increasing with experience. In contrast to much more heterogeneous samples (e.g. Albrecht et al. 1999, Kunze 2003), I do not find any differences for employees at the beginning of their career. A separate analysis for less experienced and more experienced employees with and without children is provided in Table 5 , showing that gender pay gaps are not prevalent for employees without children and with a maximum of 20 years of experience, whereas older women without children are worse off even in similar jobs. The more pronounced gender pay gaps for employees with children are hardly explained by other individual or job characteristics and are even higher for more experienced employees. Differences are also more pronounced at higher levels of firms' hierarchies (see model 3 of Table 4). Interacting the female dummy with field of study, tenure, firm size, functional area, or year dummies (not reported) does not lead to significant results. 
Table 3: Wage regressions on log total compensation (random effects)

\begin{tabular}{|c|c|c|c|c|c|c|}
\hline & \multicolumn{2}{|c|}{ (1) } & \multicolumn{2}{|c|}{ (2) } & \multicolumn{2}{|c|}{ (3) } \\
\hline Female & $-0.168 * * *$ & $(0.012)$ & $-0.075^{* * *}$ & $(0.010)$ & $-0.058 * * *$ & $(0.009)$ \\
\hline Experience & & & $0.061 * * *$ & $(0.001)$ & $0.050 * * *$ & $(0.001)$ \\
\hline Experience squared $(* 100)$ & & & $-0.087 * * *$ & $(0.003)$ & $-0.077 * * *$ & $(0.003)$ \\
\hline \multicolumn{7}{|c|}{ Field of study (base:chemistry) } \\
\hline Engineering & & & $0.081 * * *$ & $(0.010)$ & $0.069 * * *$ & $(0.009)$ \\
\hline Biology & & & $-0.032 * * *$ & $(0.012)$ & $-0.023 * *$ & $(0.011)$ \\
\hline Physics & & & 0.004 & $(0.015)$ & -0.004 & $(0.014)$ \\
\hline Medical science & & & $0.103^{* * *}$ & $(0.018)$ & $0.120^{* * *}$ & $(0.017)$ \\
\hline Pharmaceutics & & & $0.030 * * *$ & $(0.010)$ & $0.043 * * *$ & $(0.010)$ \\
\hline Other natural science & & & 0.002 & $(0.012)$ & 0.004 & $(0.011)$ \\
\hline Tenure & & & & & $0.007 * * *$ & $(0.0004)$ \\
\hline \multicolumn{7}{|c|}{ Level of hierarchy (base: Level 4) } \\
\hline Level 2 & & & & & $0.190 * * *$ & $(0.006)$ \\
\hline Level 3 & & & & & $0.067 * * *$ & $(0.004)$ \\
\hline \multicolumn{7}{|c|}{ Functional area (base: production) } \\
\hline Research and development & & & & & $-0.026 * * *$ & $(0.006)$ \\
\hline Technology & & & & & -0.011 & $(0.010)$ \\
\hline Applications engineering & & & & & -0.006 & $(0.008)$ \\
\hline Sales, marketing, logistics & & & & & $0.015^{* *}$ & $(0.008)$ \\
\hline Finance, controlling, HR & & & & & -0.003 & $(0.010)$ \\
\hline Technical supervision & & & & & $-0.054 * * *$ & $(0.009)$ \\
\hline IT & & & & & -0.015 & $(0.016)$ \\
\hline Other & & & & & $-0.019 * * *$ & $(0.007)$ \\
\hline \multicolumn{7}{|c|}{ Firm size (base: less than 100 employees) } \\
\hline 101 to 300 & & & & & $0.070^{* * *}$ & $(0.011)$ \\
\hline 301 to 1,000 & & & & & $0.120^{* * *}$ & $(0.011)$ \\
\hline 1,001 to 2,000 & & & & & $0.176^{* * *}$ & $(0.011)$ \\
\hline 2,001 to 5,000 & & & & & $0.181 * * *$ & $(0.011)$ \\
\hline 5,001 to 10,000 & & & & & $0.211 * * *$ & $(0.011)$ \\
\hline 10,001 to 30,000 & & & & & $0.251 * * *$ & $(0.010)$ \\
\hline More than 30,000 & & & & & $0.267 * * *$ & $(0.011)$ \\
\hline Year Dummies (5) & \multicolumn{2}{|c|}{ Yes } & \multicolumn{2}{|c|}{ Yes } & \multicolumn{2}{|c|}{ Yes } \\
\hline Intercept & $11.54^{* * *}$ & $(0.005)$ & $10.76^{* * *}$ & $(0.014)$ & $10.59 * * *$ & $(0.016)$ \\
\hline Observations & \multicolumn{2}{|c|}{16,029} & \multicolumn{2}{|c|}{16,029} & \multicolumn{2}{|c|}{16,029} \\
\hline R-squared overall & \multicolumn{2}{|c|}{0.034} & \multicolumn{2}{|c|}{0.430} & \multicolumn{2}{|c|}{0.590} \\
\hline
\end{tabular}

Notes: Standard errors in parentheses. *, ** and *** indicate significance at the $0.10,0.05$, and 0.01 levels. 
Table 4: Wage regressions on log total compensation with interactions (random effects)

(1) (2) (3)

\begin{tabular}{|c|c|c|c|c|c|c|c|c|}
\hline Female & $-0.035^{* * *}$ & $(0.010)$ & 0.009 & $(0.018)$ & $-0.046 * * *$ & $(0.010)$ & 0.021 & (0.019) \\
\hline Children (1=yes) & $0.025^{* * *}$ & $(0.005)$ & & & & & $0.024 * * *$ & $(0.005)$ \\
\hline Female * Children & $-0.057 * * *$ & $(0.016)$ & & & & & $-0.045^{* * *}$ & $(0.016)$ \\
\hline Female * Experience & & & $-0.0040^{* * *}$ & $(0.001)$ & & & $-0.0031 * * *$ & $(0.0010)$ \\
\hline Female * Level 2 & & & & & $-0.061^{* * *}$ & $(0.021)$ & $-0.046 * *$ & $(0.021)$ \\
\hline Female * Level 3 & & & & & -0.016 & (0.011) & -0.006 & $(0.011)$ \\
\hline Observations & \multicolumn{2}{|c|}{16,029} & \multicolumn{2}{|c|}{16,029} & \multicolumn{2}{|c|}{16,029} & \multicolumn{2}{|c|}{16,029} \\
\hline R-squared overall & \multicolumn{2}{|c|}{0.591} & \multicolumn{2}{|c|}{0.590} & \multicolumn{2}{|c|}{0.590} & \multicolumn{2}{|c|}{0.592} \\
\hline
\end{tabular}

Notes: Standard errors in parentheses. Control variables as in model (3) of Table 2 (experience, field of study, tenure, level of hierarchy, functional area, firm size, and year dummies). *, ** and *** indicate significance at the $0.10,0.05$, and 0.01 levels.

Table 5: Dummy for females in subgroups by experience and having children (Dependent variable: Log total compensation, random effects)

\begin{tabular}{llcc}
\hline & (1) & (2) & (3) \\
Individual characteristics & No & Yes & Yes \\
Job characteristics & No & No & Yes \\
Year dummies & Yes & Yes & Yes \\
\hline
\end{tabular}

\section{Without children}

$\begin{array}{lllllll}\begin{array}{l}\text { Experience } \leq 20 \text { years } \\ (\mathrm{n}=3,313)\end{array} & -0.015 & (0.016) & -0.005 & (0.013) & -0.002 & (0.011) \\ \begin{array}{l}\text { Experience }>20 \text { years } \\ (\mathrm{n}=2,539)\end{array} & -0.127^{* * *} & (0.026) & -0.076^{* * * *} & (0.026) & -0.048^{* *} & (0.022)\end{array}$

\section{With children}

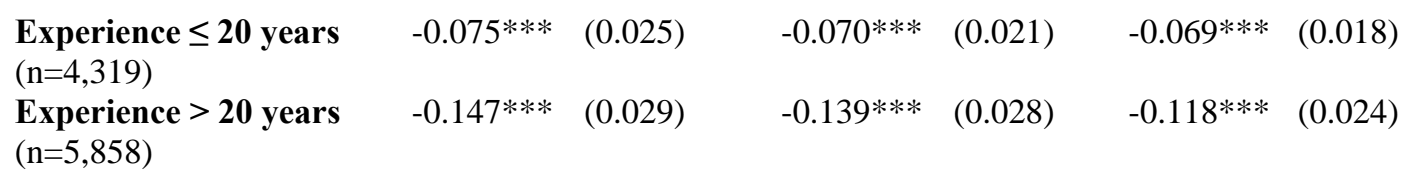

Notes: Standard errors in parentheses. ${ }^{*},{ }^{* *}$ and $* * *$ indicate significance at the $0.10,0.05$, and 0.01 levels. 
Tables 6, 7, and 8 contain estimations of the same specifications as in Tables 3 and 4 with the log of fixed salaries, bonus payments, and other payments as dependent variables (models 1 to 6). Since employees without bonuses or other payments are excluded, Tobit models with the absolute bonus and other payments as dependent variables are added here (models 7 to 12 of Tables 7 and 8). Although gender gaps in fixed salaries are somewhat smaller than for total compensation, they are still significant. Compared to fixed salaries, the gender gap for bonus payments is more than twice as large. A gap of 0.1 remains unexplained even when controlling for both individual and job-based characteristics. Gaps with respect to both are more meaningful for more experienced women and those with children. Although raw gaps for other payments even exceed those of bonus payments, there are no significant gender differences when controlling for individual and job characteristics in the log linear model. This is because of huge standard errors. The linear models abstract away from the fact that a considerably larger share of females are not considered for bonuses and other payments. Therefore, levels of significance for female dummies and interaction effects are higher when applying Tobit models.

Generally, the coefficients of female dummies shrink to roughly one third, when comparing models 1 and 3 for each wage component. Corresponding Oaxaca-Blinder decompositions (Blinder 1973, Oaxaca 1973, not reported) confirm that about two thirds of raw gender pay gaps are explained by the individual and job characteristics included in the estimations. I have also applied quantile regressions as robustness checks. Gender gaps are quite stable across the distribution and only slightly more pronounced at the bottom of the distribution, indicating slight hints at sticky floors but not at glass ceilings (see Booth et al. 2003, Arulapalam et al. 2007, Weinberger 2011) for this very specific sample of highly educated employees (note that Figure 1 in the appendix presents absolute rather than relative male-female differentials). Results of additional cross section estimations are similar across years. 
Table 6: Gender gaps in fixed salaries (random effects)

\begin{tabular}{|c|c|c|c|c|c|c|}
\hline Log fixed salaries & (1) & $(2)$ & (3) & (4) & (5) & $(6)$ \\
\hline Female & $\begin{array}{l}-0.116^{* * *} \\
(0.009)\end{array}$ & $\begin{array}{l}-0.048^{* * *} \\
(0.007)\end{array}$ & $\begin{array}{l}-0.039 * * * \\
(0.007)\end{array}$ & $\begin{array}{l}-0.021^{* * *} \\
(0.008)\end{array}$ & $\begin{array}{l}-0.005 \\
(0.014)\end{array}$ & $\begin{array}{l}-0.038 * * * \\
(0.008)\end{array}$ \\
\hline Children (1=yes) & & & & $\begin{array}{l}0.021 * * * \\
(0.021)\end{array}$ & & \\
\hline Female * Children & & & & $\begin{array}{l}-0.043^{* * *} \\
(0.012)\end{array}$ & & \\
\hline Female $*$ Experience & & & & & $\begin{array}{l}-0.002 * * * \\
(0.0007)\end{array}$ & \\
\hline $\begin{array}{l}\text { Female * Level } 2 \\
\text { Female } * \text { Level } 3\end{array}$ & & & & & & $\begin{array}{l}-0.009 \\
(0.015) \\
-0.001 \\
(0.008)\end{array}$ \\
\hline Indiv. characteristics & No & Yes & Yes & Yes & Yes & Yes \\
\hline Job characteristics & No & No & Yes & Yes & Yes & Yes \\
\hline Year dummies & Yes & Yes & Yes & Yes & Yes & Yes \\
\hline Observations & 16,029 & 16,029 & 16,029 & 16,029 & 16,029 & 16,029 \\
\hline R-squared & 0.029 & 0.482 & 0.590 & 0.592 & 0.590 & 0.590 \\
\hline
\end{tabular}

Notes: Standard errors in parentheses. *, ** and *** indicate significance at the $0.10,0.05$, and 0.01 levels. 
Table 7: Gender gaps in bonus payments (random effects GLS and Tobit models)

\begin{tabular}{|c|c|c|c|c|c|c|}
\hline $\begin{array}{l}\text { Random-effects GLS } \\
\text { Log bonus payments }\end{array}$ & (1) & (2) & (3) & (4) & (5) & (6) \\
\hline Female (female) & $\begin{array}{l}-0.334 * * * \\
(0.034)\end{array}$ & $\begin{array}{l}-0.141^{* * *} \\
(0.032)\end{array}$ & $\begin{array}{l}-0.109 * * * \\
(0.028)\end{array}$ & $\begin{array}{l}-0.062 * \\
(0.033)\end{array}$ & $\begin{array}{l}0.052 \\
(0.064)\end{array}$ & $\begin{array}{l}-0.069 \\
(0.036)\end{array}$ \\
\hline Children (1=yes) & & & & $\begin{array}{l}0.057 * * * \\
(0.017)\end{array}$ & & \\
\hline Female * Children & & & & $\begin{array}{l}-0.099 * \\
(0.055)\end{array}$ & & \\
\hline Female * Experience & & & & & $\begin{array}{l}-0.009 * * * \\
(0.003)\end{array}$ & \\
\hline Female * Level 2 & & & & & & $\begin{array}{l}-0.111 \\
(0.084)\end{array}$ \\
\hline Female * Level 3 & & & & & & $\begin{array}{l}-0.067 \\
(0.043)\end{array}$ \\
\hline Indiv. characteristics & No & Yes & Yes & Yes & Yes & Yes \\
\hline Job characteristics & No & No & Yes & Yes & Yes & Yes \\
\hline Year dummies & Yes & Yes & Yes & Yes & Yes & Yes \\
\hline Observations & 14,487 & 14,487 & 14,487 & 14,487 & 14,487 & 14,487 \\
\hline R-squared & 0.027 & 0.193 & 0.369 & 0.369 & 0.369 & 0.369 \\
\hline $\begin{array}{l}\text { Random effects Tobit } \\
\text { Bonus payments }\end{array}$ & (7) & (8) & (9) & (10) & (11) & (12) \\
\hline Female (female) & $\begin{array}{l}-7321.7^{* * *} \\
(743.2)\end{array}$ & $\begin{array}{l}-3728.7 * * * \\
(712.1)\end{array}$ & $\begin{array}{l}-2672.0^{* * *} \\
(637.1)\end{array}$ & $\begin{array}{l}-1829.7^{* *} \\
(753.3)\end{array}$ & $\begin{array}{l}1725.4 \\
(1431.7)\end{array}$ & $\begin{array}{l}-1420.7^{*} \\
(826.9)\end{array}$ \\
\hline Children (1=yes) & & & & $\begin{array}{c}893.4 * * \\
(392.2)\end{array}$ & & \\
\hline Female * Children & & & & $\begin{array}{l}-1982.5 \\
(1265.0)\end{array}$ & & \\
\hline Female * Experience & & & & & $\begin{array}{l}-255.33 * * * \\
(74.52)\end{array}$ & \\
\hline Female * Level 2 & & & & & & $\begin{array}{l}-7853.8^{* * *} \\
(1842.1)\end{array}$ \\
\hline Female * Level 3 & & & & & & $\begin{array}{l}-1227.8 \\
(975.5)\end{array}$ \\
\hline Indiv. characteristics & No & Yes & Yes & Yes & Yes & Yes \\
\hline Job characteristics & No & No & Yes & Yes & Yes & Yes \\
\hline Year dummies & Yes & Yes & Yes & Yes & Yes & Yes \\
\hline Observations & 16,029 & 16,029 & 16,029 & 16,029 & 16,029 & 16,029 \\
\hline Left censored obs. & 1,542 & 1,542 & 1,542 & 1,542 & 1,542 & 1,542 \\
\hline
\end{tabular}

Notes: Standard errors in parentheses. ${ }^{*}, * *$ and $* * *$ indicate significance at the $0.10,0.05$, and 0.01 levels. 
Table 8: Gender gaps in other payments (random effects GLS and Tobit models)

\begin{tabular}{|c|c|c|c|c|c|c|}
\hline $\begin{array}{l}\text { random effects GLS } \\
\text { Log other payments }\end{array}$ & (1) & (2) & (3) & (4) & (5) & (6) \\
\hline Female (female) & $\begin{array}{l}-0.392 * * * \\
(0.072)\end{array}$ & $\begin{array}{l}-0.163^{* *} \\
(0.068)\end{array}$ & $\begin{array}{l}-0.093 \\
(0.065)\end{array}$ & $\begin{array}{l}-0.111 \\
(0.079)\end{array}$ & $\begin{array}{l}-0.178 \\
(0.162)\end{array}$ & $\begin{array}{l}-0.102 \\
(0.036)\end{array}$ \\
\hline Children (1=yes) & & & & $\begin{array}{l}0.013 \\
(0.037)\end{array}$ & & \\
\hline Female * Children & & & & $\begin{array}{c}0.078 \\
(0.135)\end{array}$ & & \\
\hline Female * Experience & & & & & $\begin{array}{c}0.005 \\
(0.008)\end{array}$ & \\
\hline Female * Level 2 & & & & & & $\begin{array}{c}0.180 \\
(0.195)\end{array}$ \\
\hline Female * Level 3 & & & & & & $\begin{array}{l}-0.018 \\
(0.115)\end{array}$ \\
\hline Indiv. characteristics & No & Yes & Yes & Yes & Yes & Yes \\
\hline Job characteristics & No & No & Yes & Yes & Yes & Yes \\
\hline Year dummies & Yes & Yes & Yes & Yes & Yes & Yes \\
\hline Observations & 9,842 & 9,842 & 9,842 & 9,842 & 9,842 & 9,842 \\
\hline R-squared & 0.011 & 0.137 & 0.206 & 0.206 & 0.206 & 0.206 \\
\hline $\begin{array}{l}\text { Random effects Tobit } \\
\text { Other payments }\end{array}$ & (7) & (8) & (9) & (10) & (11) & (12) \\
\hline Female (female) & $\begin{array}{l}-9554.9 * * * \\
(1001.7)\end{array}$ & $\begin{array}{l}-5817.3^{* * *} \\
(998.4)\end{array}$ & $\begin{array}{l}-4215.1^{* * *} \\
(943.0)\end{array}$ & $\begin{array}{l}-4284.4^{* * *} \\
(753.3)\end{array}$ & $\begin{array}{l}-2608.7 \\
(2275.8)\end{array}$ & $\begin{array}{l}-3337.6^{* *} \\
(1348.3)\end{array}$ \\
\hline Children (1=yes) & & & & $\begin{array}{l}-126.89 \\
(604.0)\end{array}$ & & \\
\hline Female * Children & & & & $\begin{array}{c}87.16 \\
(1981.1)\end{array}$ & & \\
\hline Female * Experience & & & & & $\begin{array}{l}-89.59 * * * \\
(115.6)\end{array}$ & \\
\hline Female * Level 2 & & & & & & $\begin{array}{l}-4328.3 \\
(2980.7)\end{array}$ \\
\hline Female * Level 3 & & & & & & $\begin{array}{l}-954.93 \\
(1725.8)\end{array}$ \\
\hline Indiv. characteristics & No & Yes & Yes & Yes & Yes & Yes \\
\hline Job characteristics & No & No & Yes & Yes & Yes & Yes \\
\hline Year dummies & Yes & Yes & Yes & Yes & Yes & Yes \\
\hline Observations & 16,029 & 16,029 & 16,029 & 16,029 & 16,029 & 16,029 \\
\hline Left censored obs. & 6,187 & 6,187 & 6,187 & 6,187 & 6,187 & 6,187 \\
\hline
\end{tabular}

Notes: Standard errors in parentheses. *, ** and *** indicate significance at the $0.10,0.05$, and 0.01 levels. 


\section{Conclusion}

The results of this contribution reveal that there are meaningful gender pay gaps even for a quite homogeneous, well-educated group of employees working in one specific sector in similar jobs. In particular, these gaps are relevant for more experienced employees, those with children, and at higher levels of firms' hierarchies, respectively. The question arises as to, whether the experience effect will continue in the future. Discussions with practitioners reveal that several firms have started to adapt wages in the course of returning from parental leave in accordance with the average increases that occurred during that period, for instance. Besides, parental leave for males recently has become more common, subsequent to the introduction of monetary incentives in the context of the German Parental Leave Law being reformed in 2007. These measures may lead to a convergence of gender pay gaps so that differences in experience may emerge as a generation effect in retrospect. Gaps, however, differ considerably by components of compensation. They are much higher for contingent pay than for fixed salaries. Empirical research from the lab and the field suggest that women tend to avoid competitive situations and shy away from negotiations with respect to compensation or achieve lower outcomes in negotiations (see Bertrand 2011 for a review of the literature). Male managers in the chemical sector of this study may indeed attach more importance to sufficient stakes in bonus pools, whereas fixed salaries are determined more by formal wage systems based on job requirements and responsibilities. Future research may explore in more detail the reasons and development of wage component-specific gender wage gaps. 


\section{References}

Albrecht, J.W.; Edin, P.-A.; Sundström, M.; Vroman, S.B. (1999): Career Interruptions and Subsequent Earnings: A Reexamination Using Swedish Data. Journal of Human Resources 34, 294-311.

Arulampalam, W.; Booth, A.L.; Bryan, M.L. (2007): Is there a Glass Ceiling over Europe? Exploring the Gender Pay Gap across the Wage Distribution. Industrial and Labor Relations Review 60, 163-186.

Bayard, K.; Hellerstein, J.; Neumark, D.; Troske, K. (2003): New Evidence on Sex Segregation and Sex Differences in Wages from Matched Employer-Employee Data. Journal of Labor Economics 21, 887-922.

Bertrand, M. (2011): New Perspectives on Gender. Handbook of Labor Economics (Vol. 4b). Chapter 17, 1543-1590.

Blau, F.D.; Kahn, L.M. (2006): The U.S. Gender Pay Gap in the 1990s: Slowing Convergence. Industrial and Labor Relations Review 60, 45-66.

Blinder, A. (1973): Wage Discrimination: Reduced Form and Structural Estimates. Journal of Human Resources 8, 436-455.

Booth, A.L.; Francesconi, M.; Frank, J. (2003): A Sticky Floors Model of Promotion, Pay, and Gender. European Economic Review 47, 295-322.

Christofides, L.N.; Polycarpou, A.; Vrachimis, K. (2013): Gender Wage Gaps, Sticky Floors and Glass Ceilings in Europe. Labour Economics 21, 86-102.

Ejrnaes, M.; Kunze, A. (2013): Work and Wage Dynamics around Childbirth. Scandinavian Journal of Economics 115, 856-877.

Kunze, A. (2003): Gender differences in entry wages and early career wages. Annales d'Economie et Statistique 71, 245-266.

Machin, S.; Puhani, P.A. (2003): Subject of Degree and the Gender Wage Differential: Evidence form the UK and Germany. Economics Letters 79, 393-400.

Munasinghe, L.; Reif, T.; Henriques, A. (2008): Gender gap in wage returns to job tenure and experience. Labour Economics 15, 1296-1316.

Oaxaca, R.L. (1973): Male Female Wage Differentials in Urban Labor Markets. International Economic Review 14, 693-709.

Olivetti, C.; Petrongolo, B. (2008): Unequal Pay or Unequal Employment? A Cross-Country Analysis of Gender Gaps. Journal of Labor Economics 26, 621-654.

Ruhm, C.J. (1998): The Economic Consequences of Parental Leave Mandates: Lessons from Europe. The Quarterly Journal of Economics 113, 285-317.

Weinberger, C.J. (2011): In Search of the Glass Ceiling: Gender and Earnings Growth Among U.S. College Graduates in the 1990s. Industrial and Labor Relations Review 64, 949980. 


\section{APPENDIX}

Figure 1: Distribution of compensation by sex
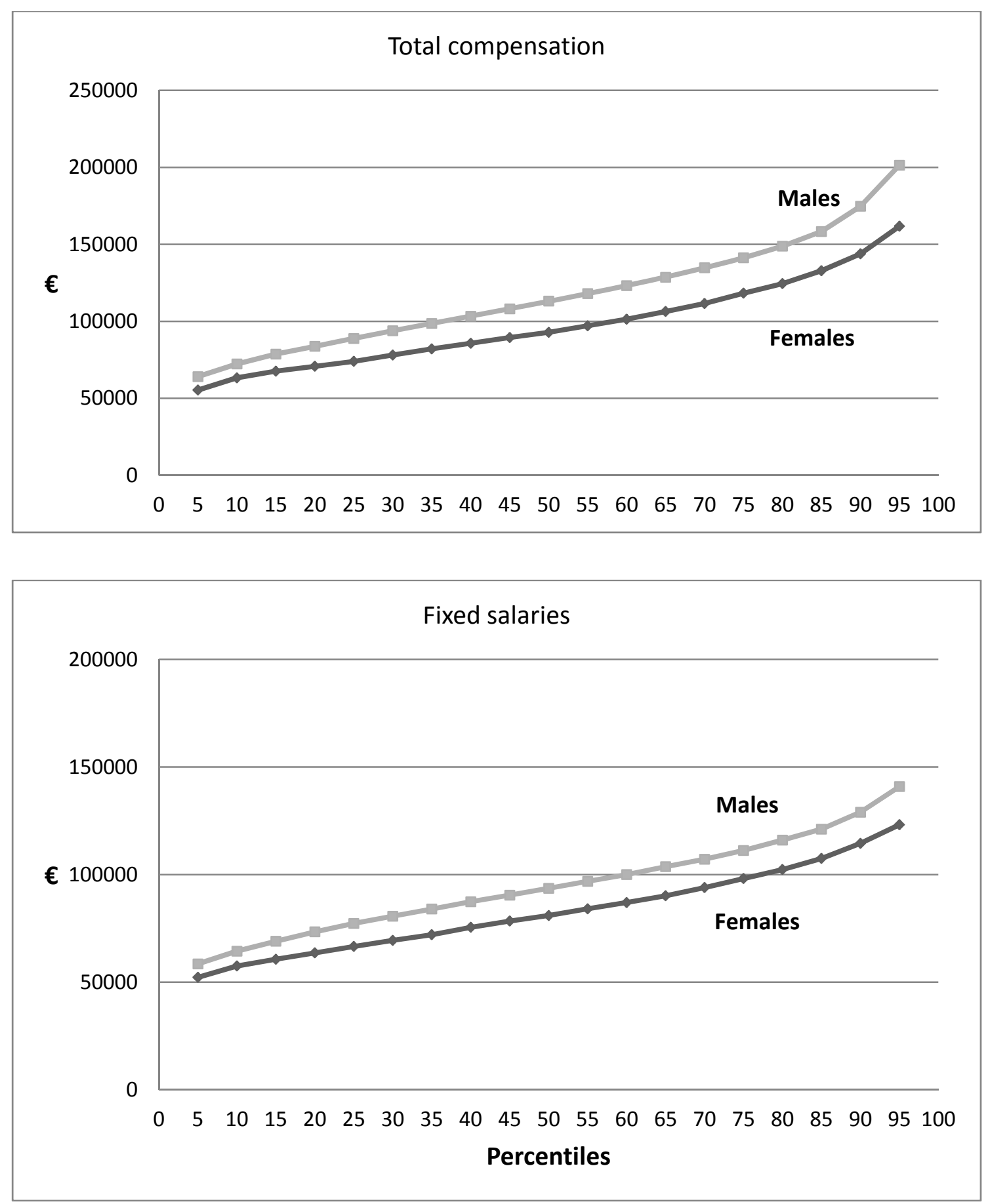

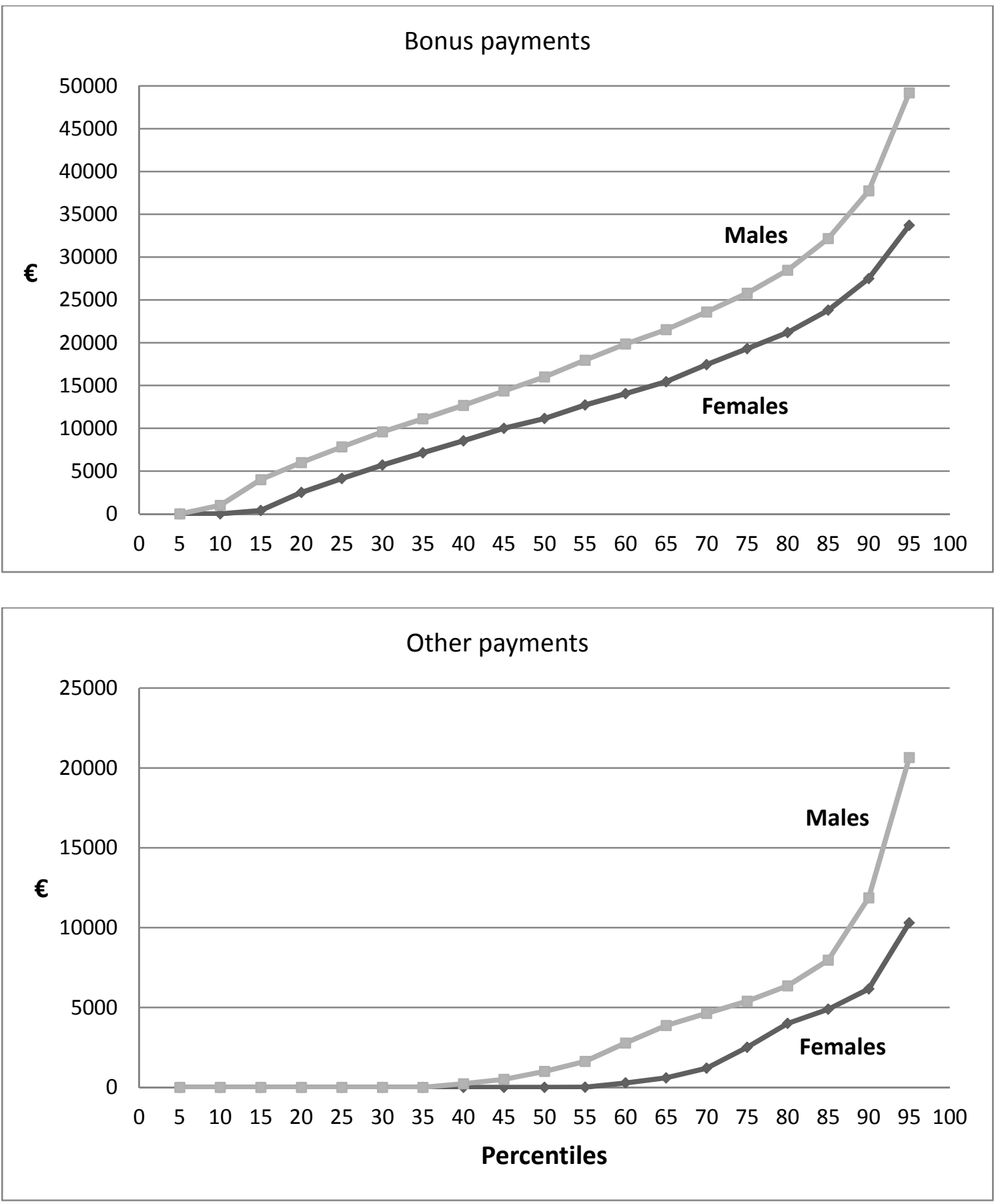